\title{
Optimization of a promising technology to degrade the persistent azo-dye (RO16) using boron doped diamond electrodes
}

\author{
Otimização de uma tecnologia promissora para degradar o \\ corante-azo (RO16), utilizando eletrodos de diamante dopado com boro
}

\author{
Fernanda Lanzoni Migliorini ${ }^{1}$, Marcela D. Alegre ${ }^{1}$, Suellen A. Alves ${ }^{2}$, Maurício R. Baldan ${ }^{1}$, \\ Marcos R.V. Lanza², Neidenei G. Ferreira ${ }^{1}$
}

\begin{abstract}
The electrochemical degradation of the reactive orange 16 azo-dye (RO16) using boron doped diamond (BDD) electrodes grown on titanium substrate (BDD/Ti) is presented. Two different electrodes, produced at growth times of 7 and $24 \mathrm{~h}$, were used and named as E1 and E2, respectively. Both of them are highly doped, with the acceptor concentration of around $7.0 \times 10^{20} \mathrm{~cm}^{-3}$, evaluated by the Raman spectra. The morphological and the physical characterization confirmed the best diamond purity of E2 electrode associated with its largest and well faceted grains as well as with its lowest $\mathrm{sp}^{2}$ content. This behavior was attributed to the diamond columnar growth dominance after the stead state process, observed for the films with a thickness higher than $3.0 \mathrm{~mm}$. The electrode efficiencies were studied to degrade electrochemically the RO16 dye. The results were analyzed by UV/VIS spectroscopy, by total organic carbon (TOC) and by high-performance liquid chromatography (HPLC) techniques. The electrode E2 showed the best efficiency for both, the aromaticity reduction and the azo group fracture, from UV/VIS spectra. These tendencies were confirmed by the TOC and the chromatographic measurements. The direct relationships among the BDD morphology, physical property, and performance during the degradation process were discussed.
\end{abstract}

Keywords: Electrochemical oxidation; Reactive orange 16 dye; Boron doped diamond.

\section{Resumo}

É apresentada neste trabalho a degradação eletroquímica do corante Reativo alaranjado 16 (RO16) utilizando eletrodos de diamante dopado com boro sobre substrato de titânio (BDD/Ti). Dois eletrodos diferentes, produzidos com tempo de crescimento de 7 e $24 \mathrm{~h}$, foram utilizados e denominados como E1 e E2, respectivamente. Ambos são altamente dopado, com a concentração de aceitador de cerca de 7,0 $\times 10^{20} \mathrm{~cm}^{-3}$, avaliadas por meio dos espectros de Raman. As caracterizações morfológicas e estruturais confirmaram a melhor pureza do diamante no eletrodo E2 associada aos seus grãos maiores e bem facetados, bem como sua menor concentração de $s p^{2}$ no filme. Este comportamento foi atribuído ao domínio de crescimento colunar diamante, observado para as películas com uma espessura superior a 3,0 $\mathrm{mm}$. As eficiências de eletrodos foram estudados para degradar electroquimicamente o corante RO16. Os resultados foram analisados por espectroscopia UV/Vis, por Carbono Orgânico Total (COT) e por Cromatografia Líquida de Alta Eficiência (HPLC). A partir dos espectros UV/Vis o eletrodo E2 apresentou a melhor eficiência na redução da aromaticidade e na quebra do grupo azo. Estas tendências foram confirmadas pelas medidas de cromatografia. Foram discutidas as relações diretas entre a morfologia dos filmes $B D D$, propriedade física e desempenho durante o processo de degradação.

Palavras-chave: Oxidação eletroquímica; Corante reativo alaranjado 16; Diamante dopado com boro.

\footnotetext{
'Instituto Nacional de Pesquisas Espaciais - São José dos Campos/SP - Brazil

${ }^{2}$ Universidade de São Paulo - São Carlos/SP - Brazil

Author for correspondence: Fernanda L. Migliorini - Email: fernandamigliorini@yahoo.com.br
} 


\section{Introduction}

Nowadays, environmental pollution can be currently considered one of the biggest worldwide problems. The wrong exploitation of natural resources a lack of environmental conscience and information about hazardous substances have caused serious and irreversible environmental damages ${ }^{(1)}$. Many factors have contributed to increase this problem, such as excessive population growth and uncontrolled search to increase food production. However, in recent years a trend of change has been observed concerning the preservation of species and the planet itself. Many scientific studies have been used as an important tool in the development of new correct environmental technologies ${ }^{(2)}$.

Aromatic amines from azo dye reduction are recognized among hazardous chemicals under surveillance. The first concerns with human exposure to carcinogenic aromatic amines arose in the dye manufacturing industry in the late nineteenth century ${ }^{(3)}$. Therefore, the dye production intermediates, including the amines involved in other chemical manufacturing industry sectors have been the main object of attention in toxicity of the aromatic amine and carcinogenicity studies for occupational health improvement actions. More recently, the possibility of the azo dyes breaking down during the use of their constituent amines has been considered a health hazard ${ }^{(4)}$. Besides, the group containing function azo dyes has deserved the most attention, which is the largest group of dyes produced in the world.

The toxicological hazards of synthetic dyes for human health are intrinsically related to the mode and the time of exposure, such as oral ingestion, skin sensitization and respiratory sensitization. Biotransformation of these dyes may be responsible for the formation of amines, benzidine and other intermediates with mutagenic and carcinogenic character ${ }^{(4)}$. Thus, residues of dyes can be highly toxic when present in any living organism, and most of these problems are due to the nature of the organic molecules that make up the dyes. The presence of dye can be easily detected, even at low concentrations where they are practically invisible. When these effluents are discharged into the water, they can cause serious problems by changing the natural color of rivers and biological cycles, which may interfere with the process of photosynthesis ${ }^{(5)}$.

Thus, new technologies for wastewater treatment have been studied to eliminate or minimize this problem. Among them, Advanced Oxidation Processes (AOP) have appeared as an alternative methodology with high efficiency to decompose many organic compounds with selectivity ${ }^{(6-12)}$. These processes are characterized by the transformation of a large number of organic pollutants into carbon dioxide, water and inorganic anions through the degradation reactions involving oxidative transitory species, mainly the hydroxyl radical $(\bullet \mathrm{OH})$. AOP has been demonstrated to produce hydroxyl radicals electrochemically in an anodic reaction directly from the water ${ }^{(13)}$. These hydroxyl radicals react strongly with all organic substances usually by hydrogen abstraction.

In addition to its environmental compatibility, the electrochemical process presents important advantages related to its versatility, high energy efficiency, amenability of automation, and safety because it operates at mild conditions ${ }^{(14-16)}$. Electrochemical oxidation with different anodes and indirect electro-oxidation with active chlorine are typical methods for the removal of dye pollutants. It is classified as electrochemical advanced oxidation process (EAPOs) and consists of the oxidation of pollutants in an electrolytic cell by chemical reaction with electrogenerated species from the water discharge at the anode.

The boron-doped diamond (BDD) thin film seems to be a suitable electrode material to produce hydroxyl radicals by the electrochemical method. The BDD based anode is a new electrode material which has received great attention in the field of wastewater treatment for its wide potential window, low background current, very low activity for $\mathrm{O}_{2}$ evolution reaction, and high anodic potential ${ }^{(17)}$. Another advantage of using BDD electrodes for organic degradation is related to their inertness, which forbids some undesirable by-products or products that can strongly adsorb on the BDD surface. In most cases, just by rinsing the BDD surface with an appropriate solvent is enough to remove the adsorbed species. For surface passivators, such as chlorophenols ${ }^{(18)}$, nitrophenol, and aromatic amines ${ }^{(18,19)}$ this problem is solved just by applying high anodic or cathodic potentials during the electrochemical procedure. The BDD electrode is considered a "non-active" anode. In general, the accepted reactions for the mechanism involved in the mineralization of organic pollutants $(\mathrm{R})$ on the BDD, at the anode active sites $(\mathrm{M})$ and in aqueous solutions, leads to the production of adsorbed hydroxyl radicals $(\mathrm{M}(\bullet \mathrm{OH})$ ads $)$ at the BDD anode surface, which is directly responsible for the generation of the mineralization products (MP):

$\mathrm{R}(\mathrm{aq})+(n / 2) \mathrm{M}(\cdot \mathrm{OH}) \mathrm{ads} \rightarrow(n / 2) \mathrm{M}+\mathrm{MP}+(n / 2) \mathrm{H}^{+}+(n / 2) \mathrm{e}^{-}$

$\mathrm{M}(\bullet \mathrm{OH}) \mathrm{ads} \rightarrow \mathrm{M}+(1 / 2) \mathrm{O}_{2}+\mathrm{H}^{+}+\mathrm{e}^{-}$ 
Where $n$ is the number of electrons involved in the organic oxidation reactions. The reaction (1) is in competition with the reaction (2) which is correlated with the anodic discharge of $\bullet \mathrm{OH}$ radicals generating the oxygen gas. The number of electrogenerated $\bullet \mathrm{OH}$ radicals is strongly associated to their interaction with the anode surface ${ }^{(20)}$. The electrogenerated - $\mathrm{OH}$ radicals formed on the BDD from the water oxidation molecules leads to the formation of physisorbed hydroxyl. The anode surface interaction with the $\bullet \mathrm{OH}$ is so weak that it allows the direct reaction of organics with $\mathrm{M}(\cdot \mathrm{OH})$ resulting in the mineralization of organic compounds. Thus, a non-active electrode does not participate in the direct anode reaction of organics and does not provide any catalytic active site for their adsorption from the aqueous media.

On the other hand, compared to other electrodes, the so-called "active" anodes, such as $\mathrm{Pt}, \mathrm{IrO}_{2}$, and $\mathrm{RuO}_{2}$, for the initial reaction, in both kind of anodes to form $\mathrm{M}(\cdot \mathrm{OH})$, the surface of active anodes interacts strongly with $(\cdot \mathrm{OH})$. Consequently, a so-called higher oxide or superoxide (MO) may be formed. This may occur when higher oxidation states are available for a metal oxide anode, above the standard potential for the oxygen evolution $\left(\mathrm{E}^{0}=1.23 \mathrm{vs}\right.$. SHE). The redox couple $\mathrm{MO} / \mathrm{M}$ acts as a mediator in the oxidation of organics, which competes with the reaction of oxygen evolution via chemical decomposition of the higher oxide species ${ }^{(20)}$.

In this paper we present a study of the RO16 electrochemical degradation using two BDD electrodes, with different thickness, grown on titanium substrate (BDD/Ti) for 7 and 24 $\mathrm{h}$, respectively. The main objective is to show how this process may be optimized depending on the BDD film thickness, also related to the diamond electrode purity. Therefore, the efficiency of the BDD/Ti electrodes to decompose electrochemically the RO16 (Fig. 1) was evaluated under different current densities, using instrumental analytical techniques, such as the UV-Vis spectroscopy, the high performance liquid chromatography (HPLC), the ion chromatography, and the total organic carbon (TOC) analyses.

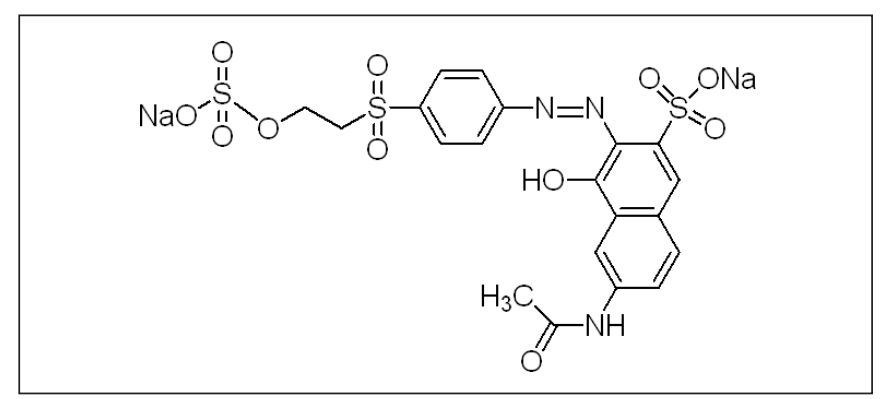

Figure 1. Structural formula of the Reactive Orange 16 (RO16) azo-dye.

\section{Experimental}

Preparation and Characterization of BDD Electrodes

The BDD electrodes were grown on Ti substrates by the hot filament chemical vapor deposition (HFCVD) technique. The deposition of diamond on titanium has a singular characteristic attributed to the strong stress formation between the film and the substrate, which arises from extrinsic and intrinsic factors. In this sense, some pre- treatments on the substrate surface are required to decrease the stress and to increase the nucleation rate ${ }^{(21-23)}$. Among them, the mechanical incision is effective to increase the titanium surface area and roughness besides improving the mechanical anchoring of the film. This incision can be obtained, for example, in air abrasion with glass beads, or by scratching the surface with an abrasive agent such as diamond paste. The treated surface ensures the best adhesion of the diamond coating due to its higher effective area for the film deposition. The $\mathrm{BDD} / \mathrm{Ti}$ with dimensions of $25 \times 25 \times 0.5 \mathrm{~mm}$ was grown from a standard gas mixture consisting of $99 \%$ of $\mathrm{H}_{2}$ and $1 \%$ of $\mathrm{CH}_{4}$. The temperature and pressure inside the chamber reactor were kept at $650^{\circ} \mathrm{C}$ and 50 Torr, respectively. The samples were grown for $7 \mathrm{~h}$ and $24 \mathrm{~h}$ of deposition time for E1 and E2 electrodes, respectively.

The doping control was obtained from an additional $\mathrm{H}_{2}$ gas flux passing through a bubbler containing a solution of $\mathrm{B}_{2} \mathrm{O}_{3}$ dissolved in $\mathrm{CH}_{3} \mathrm{OH}$ with the $\mathrm{B} / \mathrm{C}$ ratio of $15.000 \mathrm{ppm}$. This additional hydrogen flow into the reactor was controlled by a rotameter which was maintained at $40 \mathrm{sccm}$ for both experiments. The acceptor concentrations for both electrodes were evaluated by Raman spectra, with values of $6.6 \times 10^{20}$ and $7.2 \times 10^{20} \mathrm{~cm}^{-3}$ for E1 and E2, respectively, confirming the high doping for both films. The top view SEM images of BDD films were obtained from a Jeol equipment JSM-5310. The quality of BDD films was analyzed from Micro-Raman spectra recorded by a Renishaw microscope system 2000 in backscattering configuration.

Condition Monitoring and Degradation of Dye RO16

The electrochemical degradation of a degassed solution of the RO16 azo-dye supplied by Aldrich $(\sim 50 \% \mathrm{~m} / \mathrm{m})$ was performed in a polypropylene home-made single cell with capacity of $0.45 \mathrm{~L}$. The BDD/Ti working electrodes $\left(\sim 4.15 \mathrm{~cm}^{2}\right.$ of the geometric area) were located at the 
bottom of the cell. A platinum screen, $2 \mathrm{~cm}$ in diameter, was used as a counter electrode and a commercial $\mathrm{Ag} / \mathrm{AgCl}$ electrode ( $3.0 \mathrm{~mol} \mathrm{~L}^{-1} \mathrm{KCl}$ solutions) was used as the reference electrode. All the degradation assays were performed at $20^{\circ} \mathrm{C}$ and constant stirring. The solutions with $50 \mathrm{mg} \mathrm{L}^{-1}$ of the RO16 azo-dye in a $\mathrm{K}_{2} \mathrm{SO}_{4} 0.1 \mathrm{~mol} \mathrm{~L}^{-1}$ (Synth) $+\mathrm{H}_{2} \mathrm{SO}_{4} 0.1 \mathrm{~mol} \mathrm{~L}^{-1}$ (Synth) supporting electrolytes were electrolyzed at different current densities of 75, 100, 150 e $200 \mathrm{~mA} \mathrm{~cm}^{-2}$ and at 10, 20,30, 45, 60, 75 and $90 \mathrm{~min}$ periods for each current density. These procedures were adopted for both E1 and E2 electrodes. All electrochemical measurements were carried out using a potentiostat/ galvanostat AUTOLAB model PGSTAT 302 (Eco Chimie) coupled with a BRTS-10A current booster, controlled by the GPES software.

Instrumentation and analytical conditions

Concentration analyses of RO16 azo-dye were carried out with high pressure liquid chromatography (HPLC) Shimadzu 20A with UV/Visivel detector SPD-20A. The stationary fase used was a reverse fase columm $\left(\mathrm{C}_{18}\right.$ Varian Pursuit 5 250x4.6 mm) while the mobile fase was the ammonium acetate/methanol with proportion of 70:30 with flow of $0.8 \mathrm{~mL} \mathrm{~min}^{-1}$ for wavelength of the $249 \mathrm{~nm}$ at $40^{\circ} \mathrm{C}$. The ion chromatograph Pro 850 Metrohm was used to detect and to quantify the inorganic ions formed during the electrolysis. A columm A Supp 5 with mobile fase of $3.2 \times 10^{-3} \mathrm{~mol} \mathrm{~L}^{-1}$ of sodium carbonate and $1.0 \times 10^{-3} \mathrm{~mol} \mathrm{~L}^{-1}$ of sodium bicarbonate (J.T Baker) was used with flow of $0.7 \mathrm{~mL} \mathrm{~min}^{-1}$ and a conductivity detector. The Total Organic Carbon (TOC-VCPN Shimadzu) technique was employed to determine the removed organic material. The UV-Vis spectra were recorded in Varian Cary 50 Scan spectrometer in the range from 300 to $600 \mathrm{~nm}$ with quartz cubet (1 $\mathrm{cm}$ of the optic path). The maximum absorption used to calculate the concentration by UV/Vis was at wavelength of $388 \mathrm{~nm}$.

\section{Results and Discussions}

Morphological and Structural Characterization of Diamond Electrodes

The SEM images of BDD/Ti are shown in Figs. 2a and $\mathrm{b}$, which corresponds to an overview of the morphology of the E1 and E2 electrodes, grown for 7 and $24 \mathrm{~h}$, respectively.
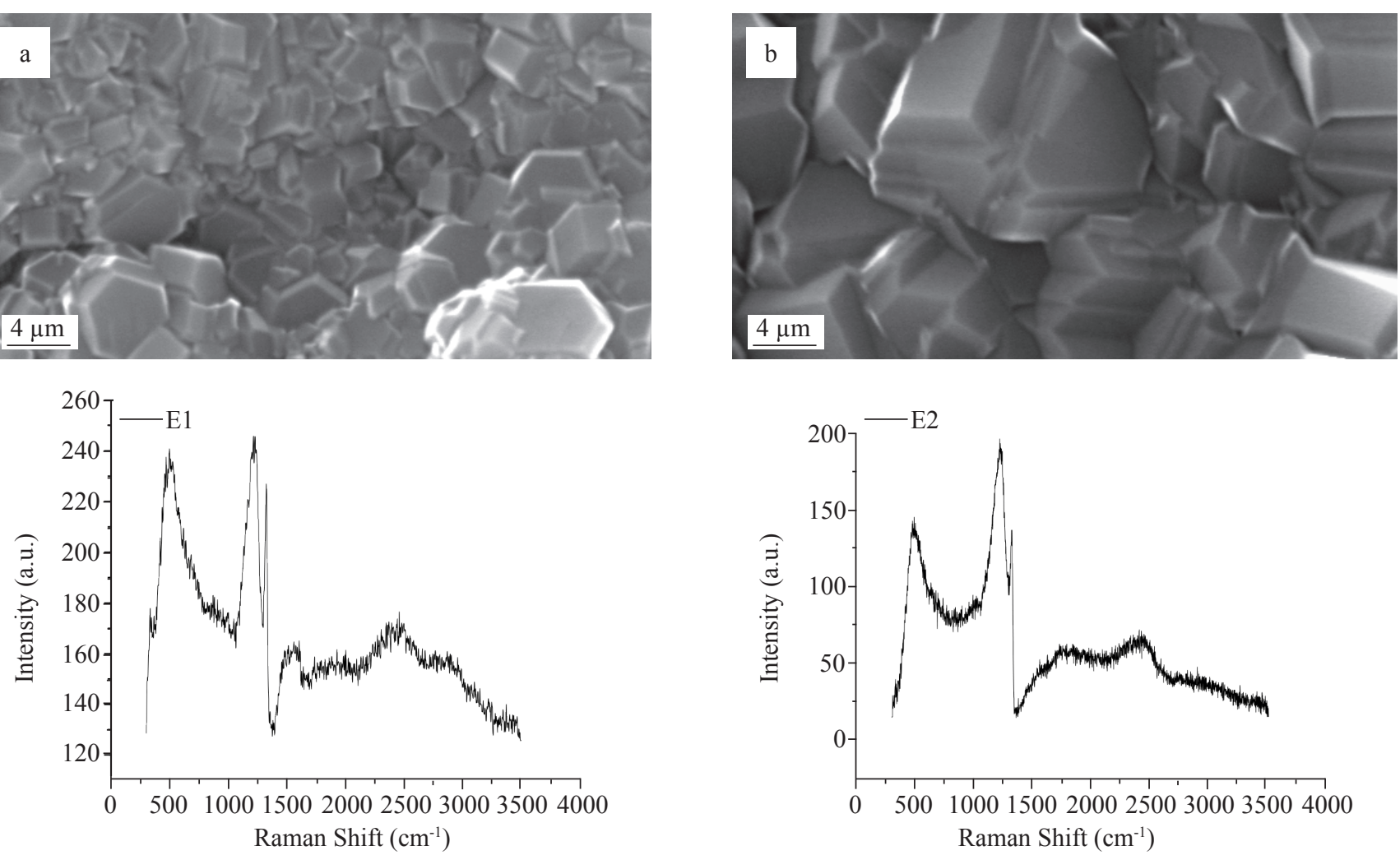

Figure 2. Scanning electron micrographs and Raman spectra. (a) E1, (b) E2 BDD films. 
Both images showed continuous and homogeneous films covering the entire substrates. Considering the challenge of growing diamond on $\mathrm{Ti}$, the films are very adherent without cracks or delaminations. This result is very important because the diamond growth on $\mathrm{Ti}$ substrates presents two problems. The first is concerns the difference of the thermal expansion coefficients between Ti and diamond. The second is related to the formation of intermediate phases such as hydrides and titanium carbides ${ }^{(24)}$. The BDD dominant morphology is associated to the microcrystalline grains randomly oriented. Particularly, due to the differences in the growth rate, the (111) and (100) crystal planes are exposed as dominant orientations, depending on the doping level. The E2 electrode shows a larger grain size with a film thickness of $5 \mu \mathrm{m}$ while for electrode E1 the thickness was around $1.0 \mu \mathrm{m}$ (Fig. 2 insets). This grain size increase is associated with the decrease in the nucleation density as a function of the deposition time, where the steady state took place with the dominant columnar growth ${ }^{(25)}$. Furthermore, a set of processes may occur during the deposition, including the disappearance of some crystals by etching or decomposition processes ${ }^{(26)}$. Particularly, the process for microcrystalline diamond follows the columnar type of growth, i.e., the first layers of the film grains grow very fast up until the process of nuclei coalescence takes place, which exhibits crystallinity due to the random nature of polycrystalline and non-oriented film ${ }^{(25)}$. An earlier paper of CVD diamond growth on silicon has shown that for a film thickness up to $3.0 \mu \mathrm{m}$ the steady state is established with the declining competitiveness of crystal orientation and also the stresses generated by the intrinsic surface accommodation. At this stage, the grains start growing as a column where their size increase is dominant over other processes, decreasing the intrinsic stress component ${ }^{(27)}$.

To investigate the composition and the quality of E1 and E2 BDD films the Raman's scattering spectra were registered and are presented in Figs. 2A and B. The presence of a Raman peak at around $1332 \mathrm{~cm}^{-1}$ was verified, which corresponds to the diamond first-order phonon vibration. We also observed the emergent band at $1200 \mathrm{~cm}^{-1}$, characteristic of the boron doped diamond films, which is attributed to the induced disorder in the diamond structure due to the boron incorporation ${ }^{(28-30)}$. This band increases significantly by increasing the doping level associated to a drastic reduction in the diamond peak.
This process is assigned to the relaxation of selection rule $\mathrm{k}=0$ of Raman scattering due to the presence of a very high concentration of boron in the diamond lattice ${ }^{(29)}$. The band around $1580 \mathrm{~cm}^{-1}$ can be attributed to band $\mathrm{G}$ (graphitic phases). The appearance of a band around $500 \mathrm{~cm}^{-1}$ is also observed, attributed to the vibration of boron pairs in diamond lattice. For electrode E2, its better quality is confirmed by the complete absence of the sharp peaks around $1580 \mathrm{~cm}^{-1}$, compared to that for electrode $\mathrm{E}^{(25)}$. As the $\mathrm{sp}^{2}$ phase is found at the grain boundary, the largest grain of E2 led to the lowest contribution of the $\mathrm{sp}^{2}$ phase when the same area is exposed to the Raman laser for both electrodes. Consequently, the thickest film presented the best quality induced by its typical diamond columnar growth.

\section{Electrochemical degradation of the dye RO16}

Both BDD samples were used to investigate the electrochemical degradation of a simulated wastewater containing the dye RO16. Some papers report the BDD as a good candidate for the degradation of organic pollutants due to its high overpotential for $\mathrm{O}_{2}$ evolution leading to a high current efficiency ${ }^{(31,32)}$. Furthermore, the BDD/Ti presents a high electric conductivity as well as a chemical and electrochemical inertia associated to its high mechanical resistance.

\section{UV/VIS analysis}

In order to evaluate the E1 and E2 efficiencies, an important parameter is the color removal during the degradation process of this species. The dye RO16 presents two bands of absorption in the visible spectrum. The first is around $390 \mathrm{~nm}$ associated with the $\pi-\pi^{*}$ transitions due to the aromatic rings. The other is around $500 \mathrm{~nm}$, attributed to the $n-\pi *$ transitions of the chromophoric azo $(-\mathrm{N}=\mathrm{N}-)$ group present in the RO16 molecule. So, the color removal of the solution containing the dye, resulting from the reaction of the chromophore groups of the molecule, can be monitored from the intensity variation of these main absorption bands. Figs. 3A and B show the absorption spectra for both electrodes from 300 to $600 \mathrm{~nm}$ for the RO16. The solutions were electrolyzed at current density of $200 \mathrm{~mA} \mathrm{~cm}^{-2}$. 

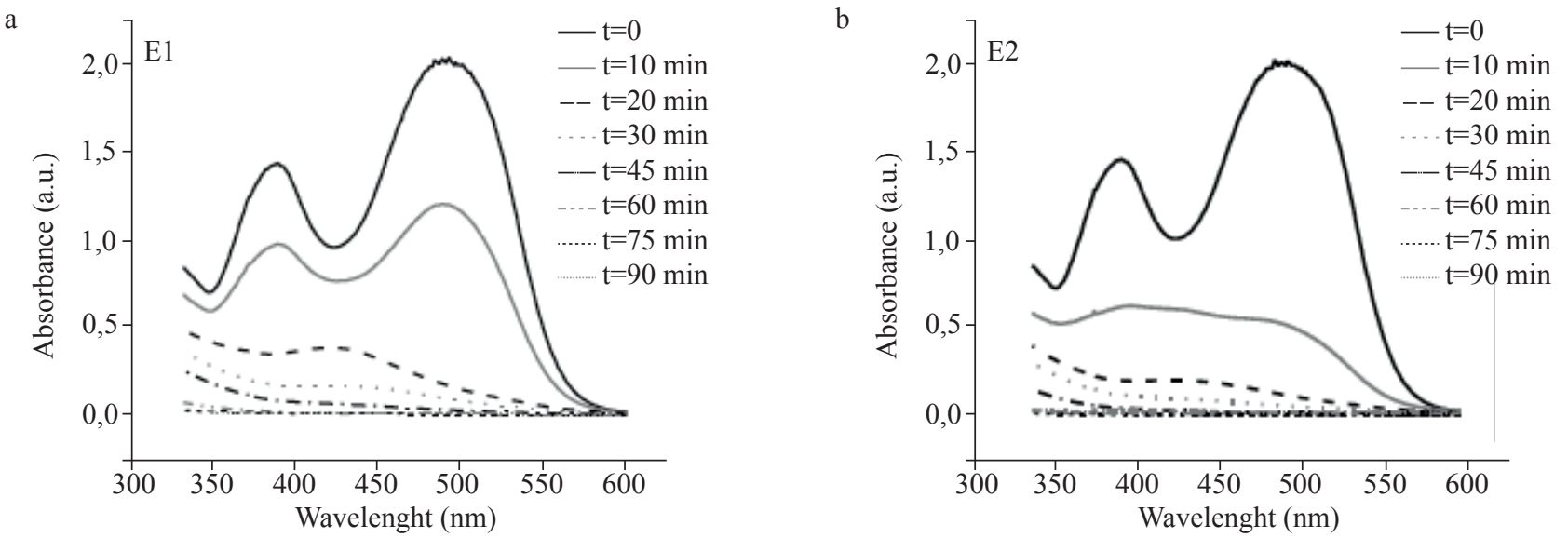

Figure 3. UV/VIS spectral changes of the RO16 azo-dye in aqueous solutions as a function of the electrolysis time of 10, 20, 30, 45, 60, 75 and $90 \mathrm{~min}$ at $200 \mathrm{~mA} \mathrm{~cm}^{-2}$ current density. (a) EI, (b) E2 electrodes.

We observed the intensity reductions for the two absorption bands as a function of the electrolysis time for E1 and E2 electrodes. Nonetheless, the electrode E2 shows an absorption bands decay of dye RO16 in a shorter time, compared to that for electrode E1. This behavior is more accentuated for electrolysis of 10, 20 e $30 \mathrm{~min}$. This result is an indication of the electrochemical treatment efficiency for the color removal using BDD electrodes, mainly for E2. The electrode E2 completely for seven times in the range from 10 to 90 min removed completely the color just after 20 min while a similar result was observed for E1 electrode only after 90 min.

For quantitative results, we used the maximum wavelength at $388,38 \mathrm{~nm}$ and a calibration curve to calculate the dye concentrations. The tests were conducted at various current densities ranging in 75, 100, 150 and $200 \mathrm{~mA} \mathrm{~cm}^{-2}$ for both $\mathrm{E} 1$ and $\mathrm{E} 2$ electrodes. The concentration decrease in the electrolyzed solutions is shown in Figs. 4a and b.

The dye concentration decays exponentially as a function of electrolysis time for all current densities studied. For both electrodes, this behavior becomes more pronounced when the applied current density is increased. The dye concentration decrease is more effective during electrolysis time of 40 min. Afterwards, this decrease is kept almost constant. The electrochemical degradation was carried out in a total time of $90 \mathrm{~min}$. For the current density of $200 \mathrm{~mA} \mathrm{~cm}{ }^{-2}$ and by using the electrode E1 with $30 \mathrm{~min}$ of treatment, a $50 \%$ decrease in the dye concentration was observed in relation to the dye initial concentration. In addition, after $30 \mathrm{~min}$ the solution was completely

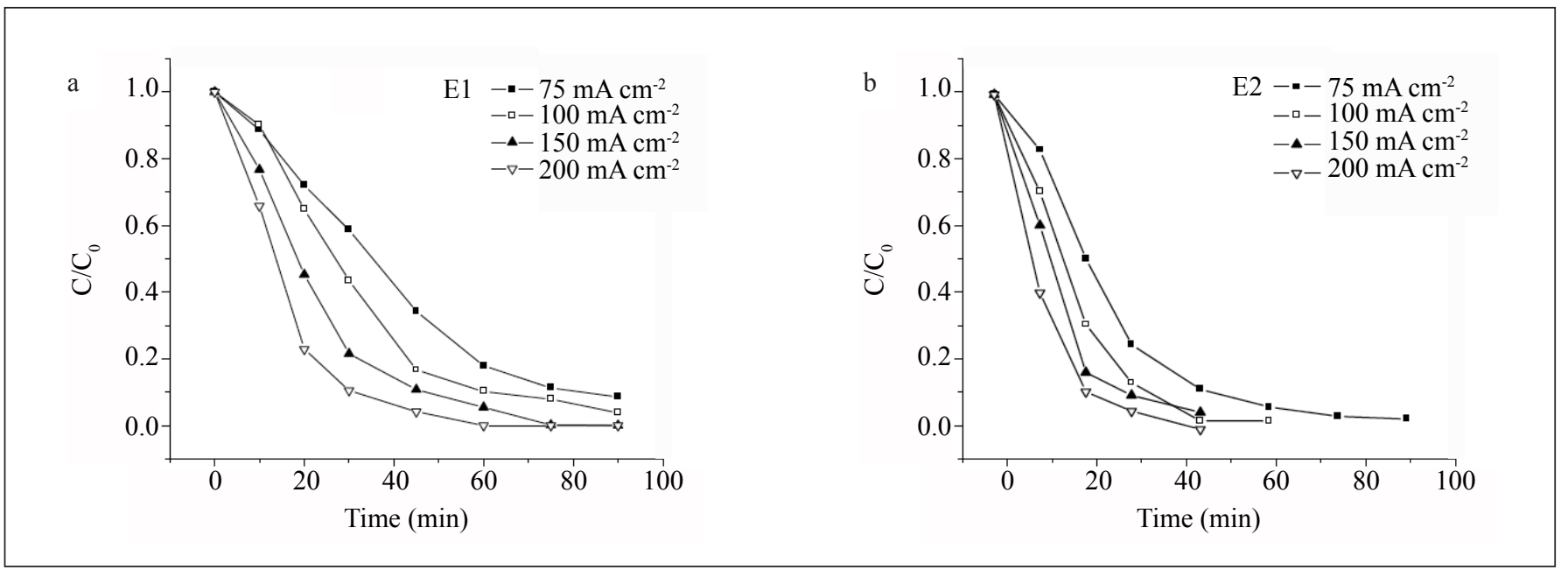

Figure 4. Variation of the RO16 azo-dye concentration at $\lambda=388 \mathrm{~nm}$ as a function of electrolysis time for the electrodegradation assays of 75, 100, 150 and $200 \mathrm{~mA} \mathrm{~cm}^{-2}$. (a) E1, (b) E2 electrodes. 
colorless. On the other hand, by using electrode E2 in similar conditions a $67 \%$ decrease in the dye concentration was observed. In this case only 20 min of treatment was sufficient to obtain a complete colorless solution.

The exponential profile of the RO16 azo-dye absorbance curves as a function of the time showed a pseudo-first order kinetic for the reactions involved in the eletrocdegradation of this colorant. The apparent kinetic constant (kapp) can be linked to the dye concentration by the Eq. $3^{(33)}$ :

$$
\ln \frac{[\text { Corante }]}{[\text { Corante }]_{0}}=-k_{a p p} t
$$

Figure 5 shows the apparent rate constants as a function of applied current density $\left(75 \mathrm{~mA} \mathrm{~cm}^{-2}\right)$ for both electrodes.

You can see that the kinetic constant increases by increasing the applied current density on both electrodes. Also, the electrode E2 showed a faster speed from the first current density compared to the electrode E1, confirming its best efficiency in removing the color of solutions containing the dye RO16.

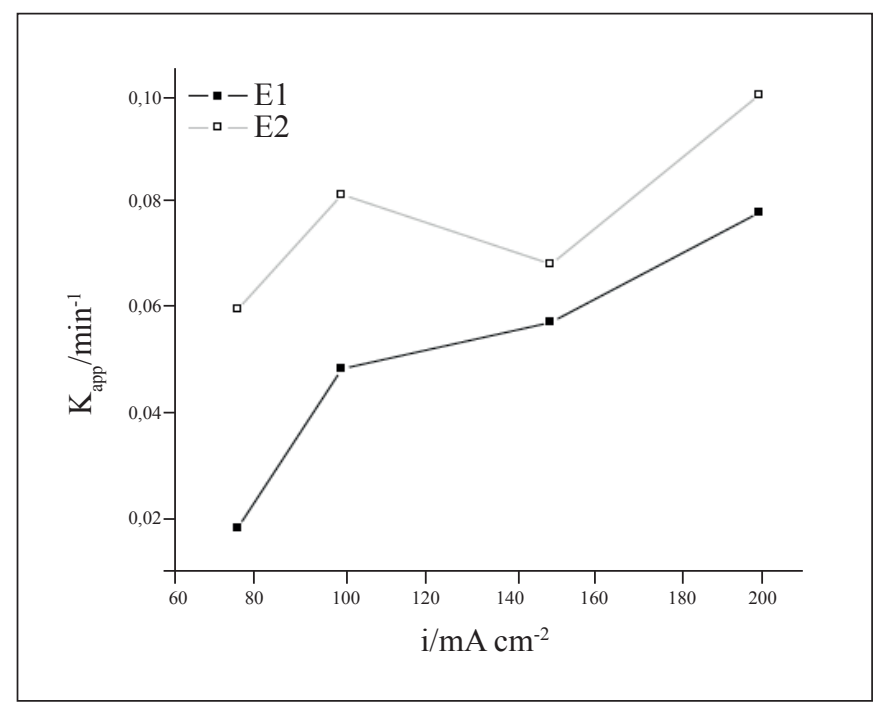

Figure 5. Kinetic constant variation from RO16 azo-dye electrodegradation process as a function of the applied current density for E1 and E2 electrodes.

\section{TOC Measurements}

TOC analyses were used to quantify the organic load present at the end of the processes of RO16 dye electrochemical degradation. This analysis is an indicattion of the efficiency of electrochemical process to mineralize the organic matter present in the dye solution. Among most of the pollution problems, toxicity, are due to the nature of the organic molecules that make up the dyes. We calculated the efficiency of mineralization at the end of each electrolysis in the whole range of current densities studied (Fig. 6), for electrodes E1 and E2, according to Eq. 4:

$$
M C E=\frac{\Delta T O C_{\text {exp }}}{\Delta T O C_{\text {teórico }}}
$$

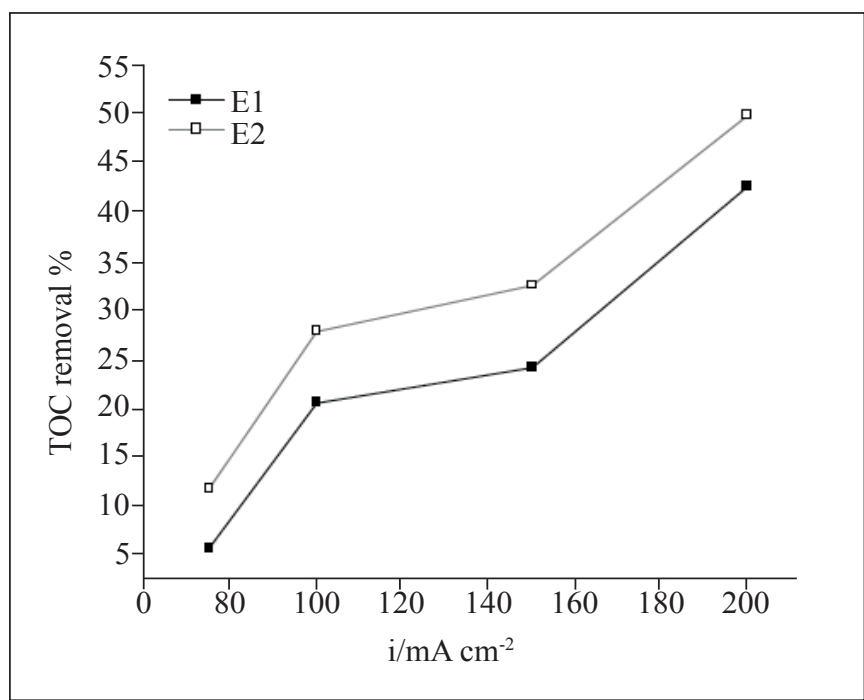

Figure 6. TOC removal efficiency as a function of the applied current densities during the electrodegradation process using E1 and E2 electrodes.

When the applied current density was increased on both electrodes, a tendency to increase the mineralization efficiency of this organic compound was observed. However, the electrode E2 has a higher percentage of mineralization of the dye RO16 in all current densities studied in comparison with the electrode E1. For the highest value of applied current density, the electrode E2 showed a TOC removal of around $50 \%$ and E1 of around $45 \%$.

\section{HPLC Qualitative Detection}

The aromatic intermediates produced during each electrochemical treatment containing RO16 dye were detected by high performance liquid chromatography (HPLC) using a wavelength of $254 \mathrm{~nm}$. The appearance of chromatographic signal at $254 \mathrm{~nm}$ is related to the $\pi-\pi^{*}$ transition of the conjugated systems, such as aromatic compounds that make up the solution of the dye RO16. Figs. 7A and B show the chromatograms of solutions containing RO16 dye untreated (1) and the solutions after electrolysis at current density of 
$200 \mathrm{~mA} \mathrm{~cm}{ }^{-2}: 10 \mathrm{~min}(2) 90 \mathrm{~min}(3)$, using E1 and E2 electrodes, respectively.
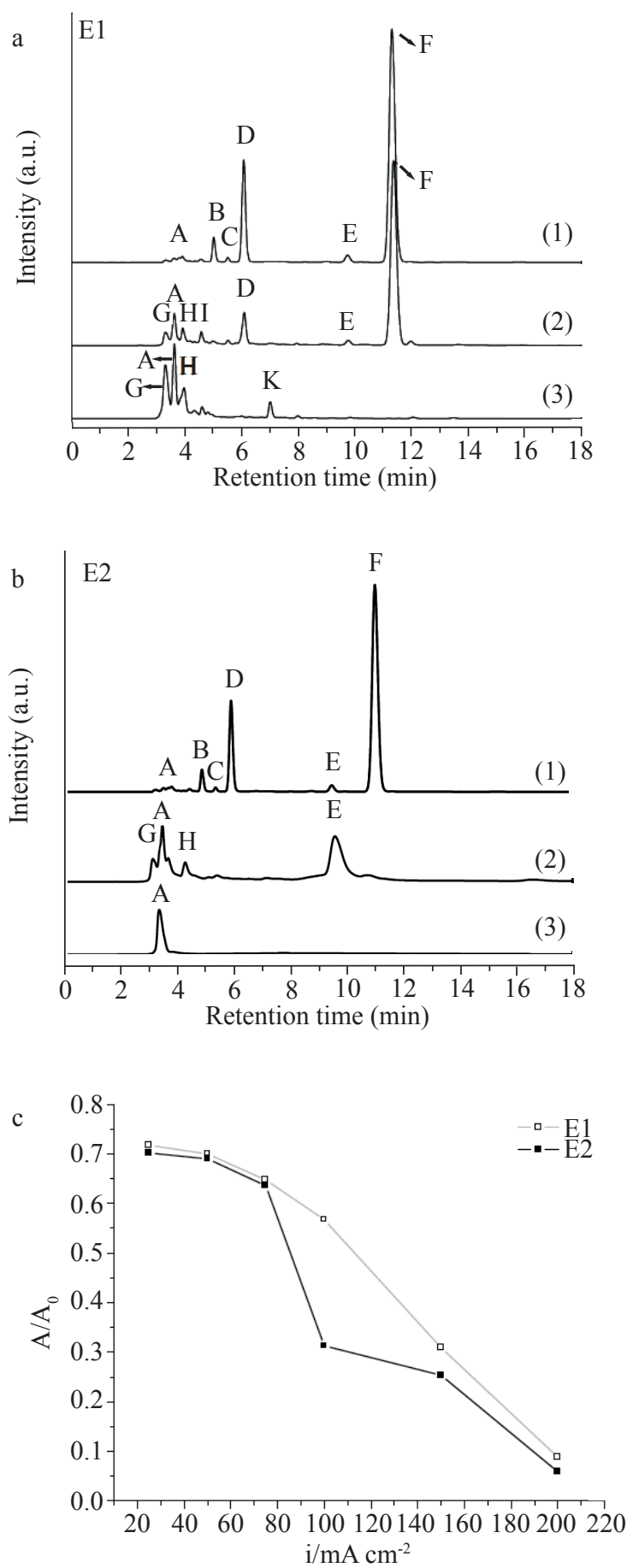

Figure 7. Chromatograms (HPLC; $\lambda=254 \mathrm{~nm}$ ) of the RO16 azodye solution $(50 \%)$ without electrochemical treatment (1) and the colorant solutions after electrochemical treatment of $90 \mathrm{~min}$ at $200 \mathrm{~mA} \mathrm{~cm}^{-2}$. (a) E1, (b) E2 electrodes, (c) Normalizes total chromatographic area as a function of the applied current for electrochemical treatment of the RO16 azo-dye solution (50\%) using E1 and E2 electrodes.
For the untreated dye solution (Chromatogram 1), at least six aromatic compounds appeared, with different polarities and retention times, named in the chromatograms as peaks from $\mathrm{A}$ to $\mathrm{F}$. The compounds concerning peaks $\mathrm{D}$ and $\mathrm{F}$, by their proportion, should be directly associated with the reactive RO16 dye. After the first 10 min of electrochemical treatment, at $200 \mathrm{~mA} \mathrm{~cm}^{-2}$ (chromatogram 2), the disappearance of the two main peaks related to the dye (D and F) is observed only when the electrode E2 was used. For electrode E1, at the same treatment time these two peaks are still very evident. After 90 min of treatment the emergence of other peaks with lower retention time is observed, for both chromatograms of the electrodes under study. This result implies the presence of compounds with more polar characteristics than that for the RO16 dye. However, for electrode E2, only one intermediate peak was detected, indicating again its best efficiency.

The above observation can be confirmed in Fig. 7C, which shows the variation of the normalized total chromatographic area as a function of current density applied to the electrodes E1 and E2. In this case, the integration of the chromatograms obtained for the solutions after each treatment can be considered a measure of the total concentration of aromatic compounds detected at $254 \mathrm{~nm}$. These results show the degradation efficiency for aromatic compounds in solutions containing the RO16 dye, for both electrodes, in addition to the byproducts degradation formed during each process. Between current density values of 75 and $100 \mathrm{~mA} \mathrm{~cm}^{-2}$ an abrupt decrease in the total dye concentration occurred using electrode E2. As the current density increases, the degradation byproducts decrease. As a result, for the current density of $200 \mathrm{~mA} \mathrm{~cm}^{-2}$, the value of the normalized total area obtained for the electrode E2 was lower than that for electrode E1. This reduction in the aromaticity of RO16 dye solution led to the possible formation of compounds of the aliphatic chain. From an environmental standpoint these compounds are very important because they tend to be biodegradable ${ }^{(34)}$.

\section{Measurements of Ion Chromatography}

In order to confirm the degradation efficiency by the breakdown of the RO16 dye molecule, the ion chromatography measurements were also carried out. This technique was used to verify possible ions formations in the processes, such as nitrate formation, as presented in Table 1. 
Table 1. Nitrate ions concentration of formed at different current densities for the electrodes as a function of deposition time.

\begin{tabular}{c|c|c}
\hline Current density $\left(\mathbf{m A ~ c m} \mathbf{~ c}^{-2}\right)$ & $\mathbf{1 5 . 0 0 0} \mathbf{~ p p m ~ - ~} \mathbf{h}$ & $\mathbf{1 5 . 0 0 0} \mathbf{p p m ~ - ~ 2 4 h}$ \\
\hline 75 & $0,0 \mathrm{mg} \mathrm{L}^{-1}$ & $0,3 \mathrm{mg} \mathrm{L}^{-1}$ \\
\hline 100 & $0,0 \mathrm{mg} \mathrm{L}^{-1}$ & $0,4 \mathrm{mg} \mathrm{L}^{-1}$ \\
\hline 150 & $0,0 \mathrm{mg} \mathrm{L}^{-1}$ & $0,5 \mathrm{mg} \mathrm{L}^{-1}$ \\
\hline 200 & $0,7 \mathrm{mg} \mathrm{L}^{-1}$ & $0,6 \mathrm{mg} \mathrm{L}^{-1}$ \\
\hline
\end{tabular}

Nitrate ions were produced in all current densities only for electrode E2 and increased monotonically from 75 to $200 \mathrm{~mA} \mathrm{~cm}^{-2}$. The electrode E1 did not show a trend in these ion formations and it appeared only at $200 \mathrm{~mA} \mathrm{~cm}^{-2}$. So, the electrode deposited for $24 \mathrm{~h}$ is more efficient in cleaving the dye molecule. This result is only an indication but it is not conclusive because the molecule breaking does not ensure that it was completely degraded.

\section{Conclusions}

The results above showed a success in the production, characterization and application of BDD/Ti electrodes, with different thickness, in the electrochemical degradation of the RO16 dye. The morphological characterization showed the diamond films completely closed without the presence of cracks. Raman analyses confirmed the good quality of diamond films. The characteristic peaks related to the presence of diamond and the influence of the dopant in the spectra were discussed. The films produced

\section{References}

1. Jardim, W. F., Revista de Química Industrial (2000) 16.

2. Legrini, O.; Oliveiros, E.; Braun, A.M., Chemical Reviews 93 (1993) 671.

3. Weisburger, J. H., Mutation Research 3769 (1997) 261.

4. Pinheiro, H. M.; Touraud, E.; Thomas, O., Dyes Pigments 61 (2004) 121

5. Kunz, A.; Mansilla, A. H.; Durán, N., Environmental Technology 23 (2002) 911.

6. Cisneros, R. L., Espinoza, A. G., Litter, M. I., Chemosphere 48 (2002) 393.

7. Miao, L.; Feng, C.; Hu, W., Zhang, Z.; Sugiura, N., Journal of Hazardous Materials 162 (2009) 455.

8. Ohsaka, T.; Shinozaki, K.; Tsurita, K.; Hirano, K., Chemosphere 73 (2008) 1279. for $24 \mathrm{~h}$ showed a typical columnar growth with well faceted grains and the lowest $\mathrm{sp}^{2}$ presence in its Raman spectrum. The electrochemical treatments showed that both BDD electrodes are effective in removing the color of the solutions associated to their TOC percentage. The HPLC showed that the intermediates formed during the degradation presented more polar character that that for RO16 dye. This behavior is associated with the probable formation of aliphatic compounds during the process. The ion chromatography analyses also confirmed the breakdown of the RO16 dye molecule due to the formation of nitrate ions as a result of this degradation. The electrode E2 was the most efficient in all these studies. This performance was associated to its best diamond purity.

\section{Acknowledgments}

The authors would like to thank FAPESP, CNPq and CAPES for the financial support.

9. Ji-Ming, H.; Zhang, J. Q.; Meng, H. M.; Zhang, J. T.; Cao, C. N., Electrochemica Acta 50 (2005) 5370.

10. Pera-Titus, M.; Garcia-Molina, V.; Baños, M.A.; Giménez, J.; Esplugas, S., Applied Catalysis B: Environmental 47 (2004) 219.

11. Panizza, M.; Cerisola, G., Journal of Electroanalytical Chemistry 638 (2010) 236.

12. Panizza, M.; Cerisola, G., Applied Catalysis B: Environmental 75 (2007) 95.

13. Cheng, S.; Fung, W.; Chan, K.; Shen, P. K., Chemosphere 52 (2003) 1797.

14. Rajeshwar, K.; Ibanez, J.G., Academic Press, 1st ed., San Diego, CA, 1997.

15. Brillas, E.; Cabot, P. L.; Casado, J., M. Tarr (Ed.), New York, 2003. 
16. Martínez-Huitle, C. A.; Ferro, S., Chemical Society Reviews 35 (2006) 1324.

17. Braga, N. A.; Cairo, C. A. A.; Matsushima, J. T; Baldan, M. R.; Ferreira, N. G., Journal of Solid State Electrochemistry 14 (2010) 313.

18. Grattrell, M.; Kirk, D.W., Journal of the Electrochemical Society 140 (1993) 903.

19. Mitadera, M.; Spataru, N.; Fujishima, A., Journal of Applied Electrochemistry 34 (2004) 249.

20. Comninellis, C.; Kapalka, A.; Malato, S.; Parsons, S. A.; Poulios, I.; Mantzavinos, D., Journal of Chemical Technology and Biotechnology 83 (2008) 769.

21. Askari, S. J.; Akhtar, F.; Chen, G. C.; He, Q.; Wang, F.Y.; Meng, X.M.; Lu, F. X., Materials Letters 61 (2007) 2139.

22. Azevedo, A. F.; Corat, E. J.; Leite, N. F.; Trava-Airoldi, V. J., Diamond and Related Materials 11 (2002) 550.

23. Barros, R.C.; Corat, E J.; Ferreira, N.G., Diamond and Related Materials 5 (1996) 1323.

24. Braga, N. A.; Cairo, C. A. A.; Almeida, E. C.; Baldan, M. R.; Ferreira, N. G., Diamond and Related Materials 17 (2008) 1891.
25. Trava-Airoldi, V. J.; Corat, E. J.; Peña, A. F. V.; Leite, N. F.; Baranauskas, V.; Salvadori, M. C., Diamond and Related Materials 4 (1995) 1255.

26. Grogler, T.; Zeilleer, E.; Dannenfeldt, M.; Rosiwal, S. M.; Singer, R. F., Diamond and Related Materials 6 (1997) 1658.

27. Ferreira, N. G.; Abramov, N. F.; Corat, E. J.; TravaAiroldi, V. J., Journal of Applied Physics 91 (2002) 2466.

28. Ager, J. W.; Walukiewicz, W.; Mccluskey, M.; Plano, M. A.; Landstrass, M. I., Applied Physics Letters 66 (1995) 616.

29. Zhang, R. J.; Lee, S. T.; Lam, Y. W., Diamond and Related Materials 5 (1996) 1288.

30. May, P. W.; Ludlow, W. J.; Hannaway, M.; Heard, P. J.; Smith, J. A.; Rosser, K. N., Diamond and Related Materials 17 ( 2008) 105.

31. Salazar-Banda, G. R.; Andrade, L. S.; Nascente, P. A. P.; Pizani, P. S.; Rocha-Filho, R. C.; Avaca, L. A., Electrochemica Acta 51 (2006) 4612.

32. Del Rio, A. I.; Molina, J.; Bonastre, J.; Cases, F., Journal of Hazardous Materials 172 (2009) 187.

33. Atkins, P.; Loretta, J., Bookman, 3rd ed., Porto Alegre, 2006.

34. Hongwei, Y.; Zhanpeng, J.; Shaoqi, S., Science of the Total Environment 322 (2004) 209. 